\title{
APLIKASI CITRA SATELIT PENGINDERAAN JAUH UNTUK PERCEPATAN IDENTIFIKASI TANAH TERLANTAR
}

\author{
The Application of Remote Sensing Satellite Imagery to Accelerate Identification of \\ Abandoned Land
}

\author{
Westi Utami', I Gede Kusuma Artika', Aziz Arisanto ${ }^{1}$ \\ 'Sekolah Tinggi Pertanahan Nasional \\ Jl. Tata Bumi No 5, Gamping, Sleman, Daerah Istimewa Yogyakarta \\ *Email: westiutami@gmail.com; kusumalemux@ymail.com; \\ stpnazisarissanto@gmail.com
}

\begin{abstract}
Identification and regulation of abandoned land needs to be intensified, to contribute identification of Objects of Agrarian Reform (TORA). Mapping of potential abandoned land carried out by the Ministry of Agrarian Affairs and Spatial Planning/National Land Agency (ATR/BPN) was considered not optimally implemented if compared between the setting targets with the achievements each year. Utilization of google earth imagery and Geographic Information System (GE and GIS) is expected accelerate mapping of potential abandoned land. Google earth image was used to interpret land cover as the basis to identify land use. Land cover classification was done using supervised classification with maximum likelihood algorithm. The results showed that google earth image and GIS were able to present existing land use, and able to identify land that has not been used as the permit rights granted. The result of interpretation and GIS analysis was expected to be used as tool to identify potential abandoned land, as the basis to regulate, accelerate and control abandoned land in Indonesia.
\end{abstract}

Keywords: Google Earth imagery, Geographic Information System, Land Abandoned.

Intisari: Identifikasi dan penertiban tanah terlantar perlu dilakukan secara intensif, salah satunya untuk memberikan sumbangan bagi Tanah Obyek Reforma Agraria (TORA). Pemetaan potensi tanah terlantar yang dilakukan Kementerian Agraria dan Tata Ruang/Badan Pertanahan Nasional (ATR/BPN) selama ini dirasa belum optimal apabila dibandingkan antara target yang ditetapkan dengan capaian setiap tahunnya. Pemanfaatan citra google earth dan Sistem Informasi Geografi diharapkan dapat membantu pekerjaan pemetaan potensi dan identifikasi tanah terlantar. Data yang digunakan adalah citra google earth untuk interpretasi tutupan tanah sebagai dasar untuk menentukan penggunaan tanah. Klasifikasi tutupan tanah pada penelitian ini menggunakan klasifikasi terselia (supervised) dengan algoritma maxsimum likelihood. Hasil penelitian menunjukkan bahwa pemanfaatan citra google earth dan SIG mampu menyajikan data penggunaan tanah eksisting terbaru, dan mampu mengidentifikasi tanah-tanah yang tidak dimanfaatkan sesuai arahan dalam izin hak yang diberikan. Hasil interpretasi dan analisis dengan SIG ini diharapkan dapat digunakan sebagai identifikasi obyek potensi tanah terlantar untuk kemudian dijadikan sebagai dasar dalam kegiatan penertiban tanah terlantar sehingga dapat membantu percepatan penertiban tanah terlantar di Indonesia.

Kata Kunci: Cira Google Earth, Sistem Informasi Geografi, Tanah Terlantar. 


\section{A. Pendahuluan}

Program kepemilikan tanah seluas 9 juta hektar yang diamanatkan pemerintahan Presiden Jokowi-JK dalam Sembilan Agenda Prioritas Nawa Cita, yaitu "mendorong land reform dan program kepemilikan tanah seluas 9 Juta Hektar" sebagaimana termuat dalam dokumen Rencana Pembangunan Jangka Menengah Nasional (RPJMN) 20152019 bertujuan agar setiap warga negara mempunyai kesempatan untuk memiliki tanah, sebagai tempat menetap atau sebagai tempat memperoleh sumber penghidupan secara layak. Reforma Agraria (RA) yang dicanangkan presiden tidak hanya sebatas pada tanah-tanah yang diatur atau menjadi kewenangan Kementerian ATR/BPN.

"RA yang digalakkan meliputi: (i) Tanahtanah legalisasi aset yang menjadi objek dan sekaligus arena pertentangan klaim antara kelompok masyarakat dengan pihak perusahaan dan instansi pemerintah, dan tanah-tanah yang sudah dihaki masyarakat namun kepastian hukumnya belum diperoleh penyandang haknya; (ii) Tanah Objek Reforma Agraria (TORA) untuk diredistribusikan kepada kelompok masyarakat miskin pedesaan; (iii) Hutan negara yang dialokasikan untuk desa dan masyarakat desa melalui skema-skema hutan adat dan perhutanan sosial termasuk Hutan Kemasyarakatan (HKm), Hutan Desa (HD), Hutan Tanaman Rakyat (HTR), dan sebagainya; dan (iv) Pengelolaan dan pengadaan lahan aset desa untuk diusahakan oleh rumah tangga petani miskin secara bersama (Perpres No 26 Tahun 2015)."

Data KementerianATR/BPN menunjukkan bahwa untuk program redistribusi tanah pada tanah-tanah Hak Guna Usaha (HGU) yang habis masa berlakunya, tanah terlantar dan tanah negara lainnya di tahun 2016 baru mencapai 175.00o bidang ( $\pm 123.280 \mathrm{Ha})$. Sementara untuk target identifikasi tanah terlantar pada tahun 2015 dari target yang ditetapkan sejumlah 119, realisasinya baru mencapai 91 dan untuk tahun 2016 dari target yang ditetapkan sejumlah 205 hanya tercapai 66. Secara khusus untuk capaian dan target terkait program penertiban dan pendayagunaan tanah terlantar tahun 2017 disajikan pada tabel 1 .

Tabel 1. Data Target dan Capaian Kinerja Kementerian ATR/BPN Tahun 2017

\begin{tabular}{|c|c|c|c|c|}
\hline No & Indikator & Target & $\begin{array}{l}\text { Realisasi/ } \\
\text { Capaian }\end{array}$ & $\begin{array}{l}\text { Prosenta- } \\
\text { se }\end{array}$ \\
\hline 1 & $\begin{array}{l}\text { Daftar isian } \\
\text { tanah terindikasi } \\
\text { terlantar di Kantor } \\
\text { Wilayah }\end{array}$ & 0,404661489 & 0,149879 & $37 \%$ \\
\hline 2 & $\begin{array}{l}\text { Identifikasi } \\
\text { Panitia C (Berita } \\
\text { Acara Panitia C) }\end{array}$ & 0,694520268 & 0,324399 & $34 \%$ \\
\hline 3 & $\begin{array}{l}\text { Usulan penertiban } \\
\text { tanah terlantar }\end{array}$ & o,883396503 & 0,032633 & $36 \%$ \\
\hline 4 & $\begin{array}{l}\text { Penertiban } \\
\text { tanah terindikasi } \\
\text { terlantar }\end{array}$ & 0,00971322 & o & o \\
\hline 5 & $\begin{array}{l}\text { Pemutakhiran } \\
\text { data tanah } \\
\text { terlantar }\end{array}$ & 2,206795439 & 1,404324 & $0.06 \%$ \\
\hline
\end{tabular}

Sumber: Laporan Kinerja Kementerian ATR/BPN Tahun 2017 (Bpn.go.id, 2018)

Tabel 1 tersebut menunjukkan bahwa capaian kinerja Kementerian ATR/BPN masih jauh dari target yang telah ditetapkan. Bahkan, pada tahun 2017, Kementerian ATR/BPN tidak menerbitkan SK penertiban tanah terlantar terhadap tanah-tanah yang sudah terindikasi terlantar. Berdasarkan data tersebut rata-rata pencapaian kinerja terkait identifikasi tanah terlantar, kegiatan identifikasi oleh Panitia C terkait identifikasi obyek serta subyek tanah terlantar, serta usulan terkait penertiban tanah terlantar baru mencapai target antara $34 \%$ $37 \%$. Angka pencapaian ini tentunya menjadi bahan evaluasi dan koreksi terhadap kinerja Kementerian ATR/BPN, khususnya pada direktorat penertiban dan pendayagunaan tanah terlantar yang ada di pusat dalam menyusun tataran kebijakan, serta strategi 
bagi kantor wilayah setingkat provinsi dan kantor pertanahan tingkat kabupaten untuk menyusun/meningkatkan strategi pencapaian kinerja.

Keberadaan tanah terlantar yang belum ditertibkan ini tentunya membawa kerugian bagi negara dan bagi masyarakat. Dalam konteks ini, di satu sisi kondisi Indonesia saat ini terdapat hamparan tanah luas yang terlantar/tidak dimanfaatkan, namun di sisi lain jutaan masyarakat kita tidak memiliki tanah sebagai sumber penghidupan. Tanah terlantar tidak hanya menyebabkan ketimpangan terhadap pemilikan, penguasaan, penggunaan, dan pemanfaatan tanah $\left(\mathrm{P}_{4} \mathrm{~T}\right)$, ketidakadilan atas aset dan ketimpangan pemerataan pembangunan, ketimpangan tingkat kesejahteraan masyarakat, namun juga menjadi salah satu obyek yang rawan terhadap timbulnya permasalahan pertanahan/agraria (konflik/sengketa) apabila tidak segera ditertibkan. Membiarkan tanah terlantar sementara masyarakat berada di bawah kemiskinan dapat diartikan menggadaikan hak-hak dan sumber penghidupan untuk memperoleh kesejahteraan bagi mereka yang berada pada kondisi kemiskinan. Pihak yang paling bertanggungjawab terhadap penertiban tanah terlantar ini adalah Kementerian ATR/ BPN. Di bawah kewenangan kementerian ini izin hak (Hak Guna Usaha, Hak Milik, Hak Guna Bangunan, Hak Pakai, Hak Pengelolaan') diberikan, sehingga yang berwenang menertibkan dan mengatur terkait $\mathrm{P}_{4} \mathrm{~T}$ adalah Kementerian ATR/BPN.

Upaya penertiban tanah terlantar diawali dengan identifikasi secara fisik terkait kondisi

1 HM dan HGB atas nama perorangan dan tanah-tanah pemerintah yang dikuasai secara langsung ataupun tidak langsung baik yang sudah maupun belum berstatus BMN/BMD yang tidak diusahakan/digunakan karena ketidaksengajaan. tanah yang ada pada suatu wilayah, apabila terindikasi terlantar maka Kementerian ATR/ BPN melalui Kantor Wilayah BPN tingkat provinsi atau Kantor Pertanahan tingkat Kabupaten/Kota akan menginventarisasi obyek tanah terindikasi terlantar tersebut. Selanjutnya panitia $\mathrm{C}^{2}$ akan melaksanakan identifikasi dan penelitian terkait obyek tanah terindikasi terlantar.

Perkembangan teknologi melalui penyajian citra google earth dan sistem informasi geografi dapat dijadikan sebagai alat untuk mempermudah pekerjaan identifikasi obyek tanah terlantar. Kelebihan citra google earth ini adalah dapat menyajikan data secara temporal (multi waktu), dengan resolusi spasial cukup baik, cakupan perekaman yang luas, dan kemampuan penyajian distribusi data spasial secara jelas (Schmidt 2016, 062-071; Ahmad 2012). Pemanfaatan citra dan SIG ini tentunya dapat membantu identifikasi potensi obyek tanah terlantar secara efektif dan efisien.

\section{B. Tanah Terlantar}

Tanah terlantar merupakan salah satu sumber tanah obyek reforma agraria (TORA). Dalam RPJM tahun 2014 - 2019 target TORA yang berasal dari HGU yang telah habis masa berlakunya dan tanah terlantar sebesar (o,6 juta hektar). Namun, di tahun 2017, data tanah yang masuk dalam daftar isian tanah terindikasi terlantar yang mampu

2 Panitia C terdiri dari: Unsur Kementerian ATR/BPN, Pemerintah Daerah, dan jajaran isntansi yang berkaitan dengan peruntukan tanah. Tugas Panitia C diantaranya adalah melakukan pengecekan terkait kondisi fisik dan yuridis, mengecek buku tanah/warkah dan berkas perencanaan penggunaan tanah yang diajukan perusahaan, melaksanakan ploting penggunaan dan pemanfaatan tanah pada peta pertanahan, menyelidiki penyebab tanah terlantar, meminta keterangan dari pemegang hak, menyusun laporan identifikasi tanah terlantar, dsb (Perkaban No 4 Tahun 2010). 
diinventarisir Kementerian ATR/BPN baru mencapai o,14 juta hektar. Adapun hingga tahun 2017 ini data luasan tanah terlantar yang dapat ditetapkan sebagai tanah clear and clean oleh Kementerian ATR/BPN baru mencapai 23.795,40 hektar (KementerianATR/BPN, 2017). Untuk mengejar target dan ketertinggalan tersebut tentunya proses percepatan terhadap penertiban tanah terlantar perlu dilakukan.

Sebagaimana diatur dalam Peraturan Presiden Nomor 11 Tahun 2010 tentang tanah terlantar serta Peraturan Kepala BPN Nomor 4 Tahun 2010 tentang Tata Cara Penertiban Tanah Terlantar dijelaskan bahwa

“Tanahyang diindikasi terlantaradalah tanah yang diduga tidak diusahakan, tidak dipergunakan, atau tidak dimanfaatkan sesuai dengan keadaan atau sifat dan tujuan pemberian hak atau dasar penguasaannya yang belum dilakukan identifikasi dan penelitian." (Perkaban No. 4 Tahun 2010).

"Tanah terlantar adalah tanah yang sudah diberikan hak oleh negara berupa Hak Milik, Hak Guna Usaha, Hak Guna Bangunan, Hak Pakai, dan Hak Pengelolaan, atau dasar penguasaan atas tanah yang tidak diusahakan, tidak dipergunakan, atau tidak dimanfaatkan sesuai dengan keadaannya atau sifat dan tujuan pemberian hak atau dasar penguasaannya." (Perkaban No. 4 Tahun 2010).

Kegiatan inventarisasi terhadap tanah terlantar dilakukan oleh Kantor Wilayah Badan Pertanahan Nasional berdasarkan hasil laporan dari Kantor Pertanahan Kabupaten/ Kota, dinas terkait, dan juga dapat berasal dari laporan masyarakat berdasarkan hasil pemantauan lapangan. Identifikasi potensi obyek tanah terlantar dilakukan berdasarkan atas pengumpulan data tekstual dan data spasial penggunaan tanah. Gambaran obyek potensi tanah terlantar di Indonesia disajikan pada gambar 1 berikut:

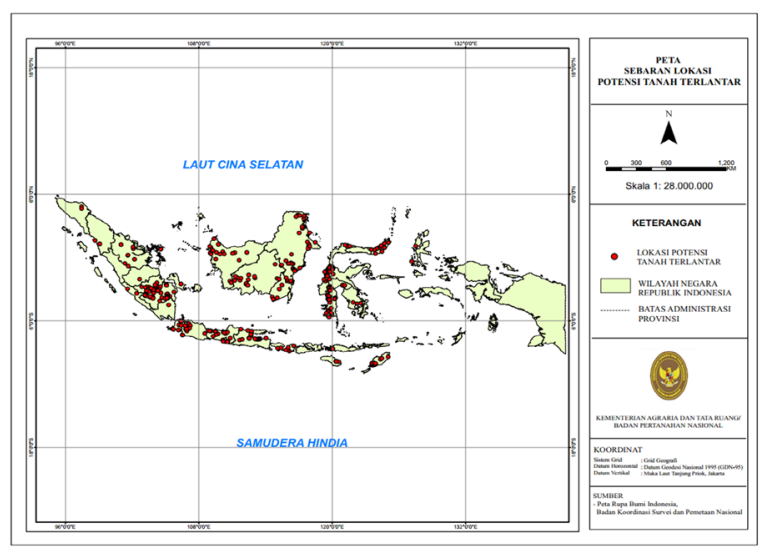

Gambar 1. Peta Sebaran Lokasi Potensi Tanah Terlantar

Sumber: Kementerian ATR/BPN, Tahun 2017

Berdasarkan gambar peta potensi tanah terlantar dan data dari Kementerian ATR/ BPN menyatakan bahwa di Indonesia masih terdapat banyak sebaran tanah terlantar yang belum teridentifikasi sehingga belum dapat dimanfaatkan/didayagunakan untuk kepentingan masyarakat melalui redistribusi tanah, cadangan tanah negara dan kepentingan pembangunan. Dari hasil wawancara dan diskusi dengan pegawai pada Direktorat Penertiban Tanah Terlantar dan Direktorat Landreform di Kementerian ATR/BPN pada tahun 2017, kelemahan program penertiban dan pendayagunaan tanah terlantar untuk Tanah Obyek Reforma Agraria terletak pada lemahnya ketersediaan data spasial pada obyek tanah terlantar yang menggambarkan kondisi eksisting penggunaan tanah, luasan tanah terlantar serta kondisi geomorfologis sebaran tanah terlantar. Selain itu belum ditetapkannya tanah pada kondisi clear dan clean menjadi kendala terkait penetapan dan pendayagunaan tanah terlantar.

Pemanfaatan citra penginderaan jauh dan SIG diharapkan mampu menghasilkan data spasial terkait obyek tanah terlantar, luasan, penggunaan tanah eksisting, dan juga memberikan gambaran kondisi geomorfologis. 
Data tersebut, didukung dengan peta kemampuan tanah serta kesesuaian tanah yang tersedia pada setiap kantor pertanahan kabupatan/kota dapat dijadikan sebagai dasar penting dalam merencanakan penetapan dan pendayagunaan tanah bekas tanah terlantar untuk reforma agraria. Hingga saat ini, datadata secara spasial terkait tanah terlantar dan data-data penunjang ini belum cukup lengkap disajikanoleh KementerianATR/BPN. Hal inilah yang menjadi tantangan pekerjaan Kementerian untuk menyusun strategi percepatan terhadap tersedianya data-data tersebut.

\section{Data dan Lokasi}

Penelitian ini dilakukan pada kawasan yang diindikasikan terdapat tanah terlantar. Akan tetapi, dikarenakan lokasi penelitian belum pernah dikaji dan diteliti oleh Kementerian ATR/BPN terkait indikasi adanya tanah terlantar, maka peneliti dalam hal ini tidak memiliki kewenangan untuk menyebutkan lokasi penelitian secara eksplisit. Data yang digunakan untuk menyusun peta potensi tanah terlantar adalah peta eksisting penggunaan tanah dan Peta HGU. Data sekunder yang dibutuhkan untuk mengetahui arahan penggunaan tanah adalah SK Hak (HGU/HP/HGB) yang diterbitkan Kementerian ATR/BPN untuk perusahaan/ pengusaha. Data serta rencana penggunaan tanah oleh perusahaan dan penetapan izin penggunaan tanah tersimpan menjadi satu berkas dalam warkah tanah yang ada di kantor pertanahan. Selanjutnya berkas dan SK ini dijadikan sebagai acuan untuk mengetahui penyimpangan terkait penggunaan tanah dan indikasi penelantaran tanah.

Selanjutnya untuk mengetahui penggunaan tanah terbaru/eksisting digunakan data citra google earth ${ }^{3}$ mencakup

3 Paulighe (2015), uji akurasi posisi, presisi dan lokasi HGU. Citra google earth merupakan citra dengan resolusi spasial cukup baik sehingga akurasinya cukup tinggi (Colin, 2014). Citra google earth yang dilaunching pada tahun 2005 ini telah banyak digunakan untuk berbagai aplikasi interpretasi tutupan lahan dan berbagai analisis spasial. Amran (2017, 1823) memanfaatkan citra google earth untuk pemetaan rumput laut, sementara Collin dkk (2014) menggunakan citra google earth untuk memetakan topografi substrat dasar laut di Shiraho, Ishigaki Jepang, dan menghasilkan peta dengan akurasi $89,7 \%$.

Citra google earth disajikan secara tidak berbayar dan mudah digunakan serta dikenali oleh pengguna. Saat ini citra google earth telah didukung oleh digital globe 4 (Farah 2014) sebagai provider. Pemanfaatan google earth engine dan citra yang disediakan oleh digital globe untuk interpretasi tutupan dan penggunaan tanah juga telah dilakukan oleh Goldblatt pada kawasan urban di India (Goldblatt 2016, 634) dan hasilnya memenuhi standar dalam hal klasifikasi dan akurasi interpretasi tutupan lahan.

Komposit yang digunakan untuk interpretasi tutupan tanah adalah dengan komposit band 3, 2, dan 1 atau true color yaitu menggunakan panjang gelombang 3 (merah), 2 (hijau) dan 1 (panjang gelombang

konsitensi terhadap citra google earth telah dilakukan pada penelitiannya di Roma Italia dengan menggunakan citra google earth tahun 2007, 2011 dan 2013. Hasil terhadap uji akurasi horizontal citra google earth dengan menggunakan GPS dan sistem fotogrameteri kadaster menunjukkan tingkat akurasi sebesar $95 \%$, dan dengan akurasi posisi sebesar $1 \mathrm{~m}$. Sehingga penggunaan citra ini dapat diturunkan untuk pemanfaatan analisis yang menghasilkan peta skala besar.

4 Digital globe merupakan penyedia satelit multispektral yang menyajikan data spasial dengan resolusi tinggi diantaranya adalah: citra IKONOS, QuickBird, GeoEye-1, WorldView-2 dan WorldView-3. 
biru). Komposit ini dipilih untuk mengetahui kondisi obyek yang ada di permukaan bumi sesuai dengan kenampakan aslinya.

Penelitian ini merupakan penelitian kualitatif dengan menggunakan analisis spasial untuk mengetahui potensi tanah terindikasi terlantar pada salah satu kawasan HGU. Identifikasi terhadap tanah potensi terlantar dilakukan dengan melakukan interpretasi penggunaan tanah eksisting yang ada pada lokasi izin HGU. Untuk mengetahui batasan HGU pada citra maka citra google earth ditumpang tindihkan dengan peta HGU. Selanjutnya, dari hasil overlay antara peta eksisting penggunaan tanah dengan peta HGU, diperoleh data kesesuaian dan ketidaksesuaian arahan penggunaan tanah HGU dengan kondisi eksisting. Beberapa lokasi HGU yang masih dibiarkan sebagai lahan kosong atau penggunaan tanahnya tidak sesuai dalam SK pemberian hak tersebut selanjutnya dikelompokkan dalam area potensi obyek tanah terindikasi terlantar. Konsep yang digunakan untuk mengidentifikasi potensi tanah terlantar adalah konsep monitoring penggunaan tanah dengan google earth ${ }^{5}$.

Klasifikasi yang digunakan untuk interpretasi adalah klasifikasi terselia (supervised). Klasifikasi ini dipilih karena peneliti dapat memberikan pengaruh terhadap klasifikasi yang akan dihasilkan melalui pengambilan sampel yang merepresentasikan nilai spektral tertentu (Lillesand and Kiefer 2008). Hal penting yang harus dipertimbangkan dalam klasifikasi terselia

5 Bey (2016) menyatakan bahwa monitoring penggunaan tanah dan tutupan tanah menggunakan citra google earth dan collect earth ini membantu untuk memudahkan pengguna data memantau penggunaan tanah sebagai bahan untuk melakukan penilaian dan evaluasi penggunaan tanah. Kemampuan ini bermanfaat untuk mewujudkan pengelolaan sumber daya alam dan lingkungan berkesinambungan. adalah sistem klasifikasi dan kriteria sampel yang diambil. Pada klasifikasi ini diawali dengan pengambilan sampel (training area) terhadap beberapa obyek yang ada dalam citra untuk selanjutnya sampel ini dijadikan acuan dalam mengklasifikasikan nilai pixel sebagai representasi kenampakan tutupan tanah yang ada pada citra google earth yang disajikan.

Algoritma yang digunakan untuk analisis klasifikasi adalah maxsimum likelihood. Algoritma ini merupakan salah satu algoritma dalam analisis klasifikasi terselia yang paling sering digunakan dan paling populer dibandingkan dengan algoritma lainnya (minimum distance to mean algorithm, K-Nearest Neighbour Algorithm dan parallelepiped) (Lu et al 2011). Algoritma ini dipilih karena nilai statistiknya lebih stabil, lebih mapan dan lebih logik dalam mengklasifikasikan setiap nilai pixel pada citra digital. Sebaran klasifikasi nilai digital diklasifikasikan berdasarkan dasarperhitungan probabilitas, dimana nilai pixel dikelaskan berdasarkan bentuk, ukuran, dan orientasi sampel pada feature space bukan berdasarkan pada jarak eklidiannya (Danoedoro 2012). Sistem klasifikasi yang diacu dalam penelitian menggunakan skema klasifikasi penggunaan lahan yang dikembangkan oleh Projo Danoedoro (2012) namun sedikit dikolaborasikan dengan pengembangan oleh peneliti menyesuaikan karakteristik daerah penelitian. Dalam sistem dan pengenalan penggunaan tanah menggunakan sistem klasifikasi terselia ini pemahaman dan pengetahuan mengenai daerah yang diteliti (local knowledge) akan sangat menunjang dan membantu pada proses klasifikasi dan interpretasi (Bronsveld et al 1992). Pemahaman terhadap daerah penelitian dalam hal ini memudahkan peneliti untuk mengenali obyek yang tersaji dalam sebuah citra, sehingga akan 
membantu pada saat proses pengambilan sampel/training area pada sistem klasifikasi terselia. Bagan alur penyusunan peta potensi tanah terlantar tersaji pada gambar 2.

Gambar 2. Diagram Alir Penyusunan Peta Tanah Terindikasi Terlantar

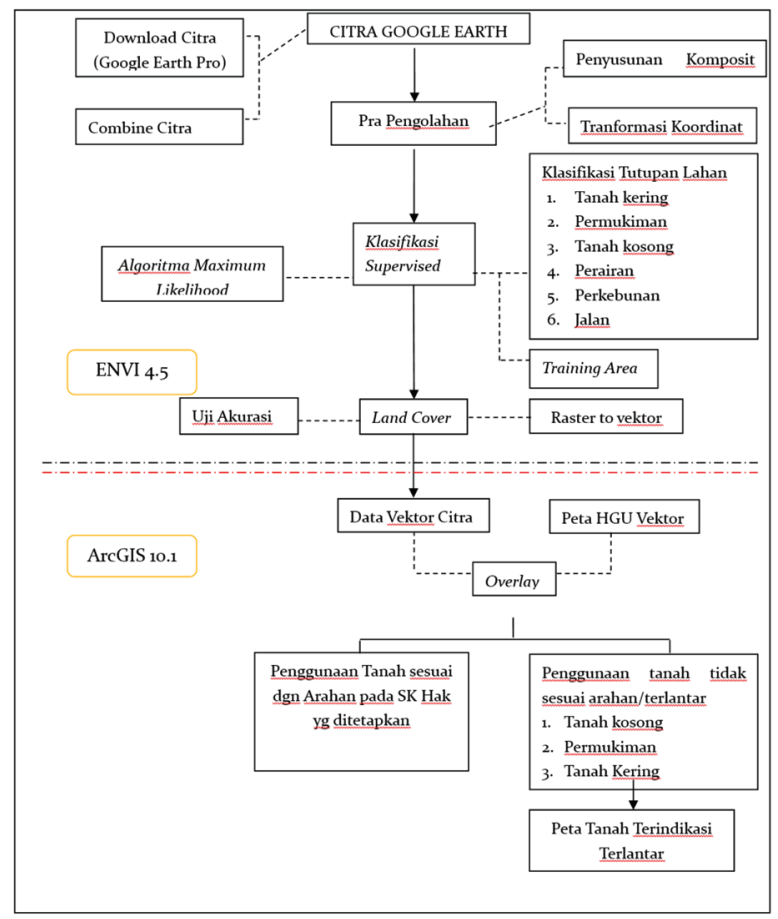

\section{Identifikasi Tanah Terlantar Menggunakan Citra Satelit Google Earth}

Perangkat lunak yang digunakan untuk melakukan analisis data digital/nilai spektral adalah ENVI 4.5. Kelebihan dari perangkat lunak ini adalah mampu memberikan hasil interpretasi secara lebih mudah, menyediakan piranti pengolahan data digital secara lengkap, dan mampu menghasilkan akurasi pengolahan data digital lebih baik. Sementara itu, penyajian secara spasial terhadap hasil klasifikasi citra digital dan untuk mempermudah terhadap analisis data spasial pada penelitian ini memanfaatkan aplikasi sistem informasi geografis.

\section{Pengolahan Citra Satelit Google Earth}

Kemajuan teknologi pengideraan jauhyang semakin pesat dan kemudahan mengakses berbagai data citra secara terbuka/online saat ini memudahkan user/pengguna dalam hal memperoleh data citra berkualitas tinggi yang tersedia secara multitemporal, serta mampu menyajikan pilihan saluran dengan berbagai multispektral/hiperspektral (Hird 2017, 1315). Tersedianya citra satelit dengan resolusi tinggi ini bisa diperoleh dengan berbagai teknik dan dapat diambil dari berbagai situs resmi dunia. Khusus untuk penelitian ini, peneliti menggunakan citra satelit google earth pro yang direkam pada tanggal 23 Oktober 2017. Alasan pemilihan citra google earth pro adalah citra ini memiliki kualitas resolusi spasial tinggi, dengan cakupan perekaman luas, dan dapat diunduh secara free.

Aplikasi yang digunakan untuk memperoleh citra adalah dengan aplikasi $U M D$ 9.37. Hal penting yang dilakukan dalam mendownload citra adalah user harus terlebih dahulu mengetahui koordinat lokasi yang diinginkan untuk selanjutnya dapat memasukkan koordinat lintang dan koordinat bujur obyek/lokasi pada software UMD 9.37. Selanjutnya citra yang sudah terdownload tersebut memerlukan proses combine file untuk menggabungkan file yang jumlahnya ribuan dengan menggunakan tool maps combiner yang tersedia pada aplikasi $U M D$ 9.37. Keuntungan menggunakan aplikasi ini adalah hasil download citra google earth dapat disajikan dalam format TIFF dan dengan dimasukkannya koordinat lintang bujur pada proses sebelumnya maka citra yang disajikan sudah memiliki georeferensi. Hasil download citra google earth dengan komposit 321 (true colour) disajikan pada gambar 3 . 
Gambar 3. Citra Google Earth Daerah Penelitian

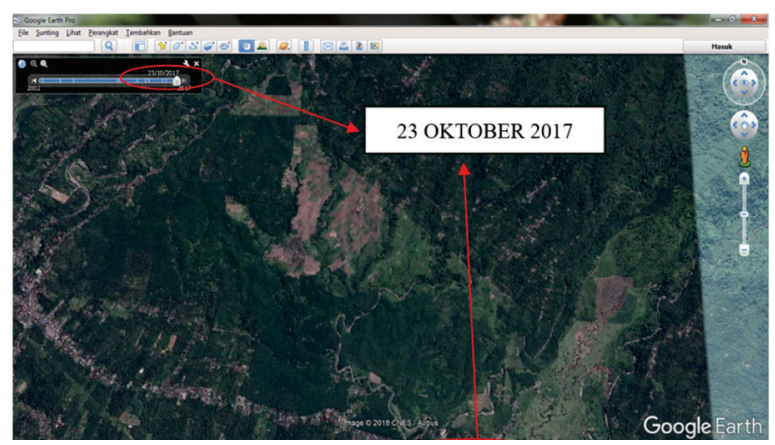

(sumber: Google Earth, 2017)

Gambar 3 citra google earth komposit 321 menunjukkan bahwa kenampakan tutupan lahan yang ada sesuai dengan warna asli dengan obyek yang ada di permukaan bumi. Tutupan lahan berupa vegetasi ditunjukkan dengan warna hijau, dimana pada vegetasi dengan kerapatan tinggi ditunjukkan dengan warna hijau tua, sementara untuk vegetasi dengan kerapatan rendah ditunjukkan dengan warna hijau muda. Pengenalan obyek secara mudah dapat diamati dari tampilan citra google earth, beberapa obyek yang tampak seperti adanya tanah terbuka/tanah kosong ditunjukkan dengan warna coklat, dan untuk tubuh air yaitu sungai juga sangat mudah dikenali dengan bentuknya yang memanjang dan berkelok-kelok.

Pengolahan data digital pada penelitian ini menggunakan analisis klasifikasi terselia (supervised) dengan algoritma maxsimum likelihood. Klasifikasi ini memudahkan user/ pengguna untuk memberikan intervensi terhadap jumlah klasifikasi yang diinginkan sebagai dasar proses analisis lebih lanjut. Beberapa hal yang harus diperhatikan dalam proses klasifikasi ini adalah user harus teliti dalam mengambil training area sebagai sampel yang digunakan untuk setiap jenis tutupan tanah.

Sebagai upaya memberikan sampel yang baik, pengambilan training area meliputi: pengambilan sampel secara merata kurang lebih 10 lokasi terhadap kenampakan visual obyek yang sama (dengan mengacu pada warna, rona, asosiasi, dan tekstur yang sama), memenuhi standart nilai pixel minimum yang harus diambil dalam setiap sampel yaitu sejumlah 100, pengambilan sampel pada jenis pixel pure pixel/ sampel yang homogen. Dengan terpenuhinya training area ini maka uji separabilitas (uji keterpisahan) antara pixel satu dengan lainnya memenuhi standart yaitu diperoleh hasil uji separabilitas antara 1,7 1,9. Uji separabilitas menjadi salah satu poin penting dalam klasifikasi citra terselia. Semakin baik tingkat uji separabilitas yaitu mendekati angka 1,9 menandakan bahwa antara pixel satu dengan pixel lain dengan nilai spektral yang berbeda dapat terpisah dengan baik. Uji ini menjadi penentu terhadap proses klasifikasi yang akan dihasilkan dan menjadi penentu apakah proses klasifikasi dapat dilanjutkan atau tidak. Apabila user belum memenuhi nilai uji separabilitas maka proses pengambilan sampel harus dilakukan secara ulang.

\section{Gambar 4. Hasil Klasifikasi Citra Google Earth}

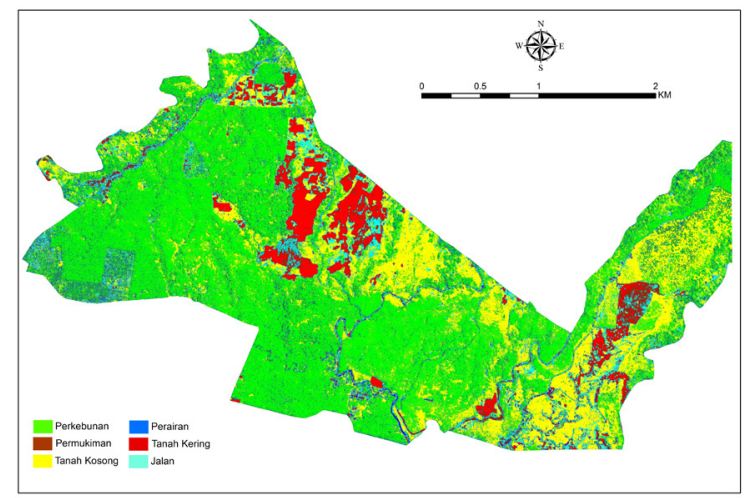

(Sumber: Hasil Analisis Citra Google Earth)

Klasifikasi tutupan tanah pada citra google earth ini mencakup 6 kriteria yaitu: tanah kering, permukiman, tanah kosong, perairan, perkebunan, dan jalan. Dari hasil pengolahan data citra secara digital dengan software Envi 4.5 diperoleh klasifikasi tutupan tanah sebagaimana tersaji pada gambar 4 . 
Data dan luasan pengolahan citra secara digital diperoleh klasifikasi tutupan tanah tersaji pada tabel 2.

Tabel 2. Klasifikasi Tutupan Tanah Pada

\section{Lokasi HGU}

\begin{tabular}{llll}
\hline No & Klasifikasi & Luas & Prosentase \\
& Penggunaan Tanah & $(\mathrm{Ha})$ & \\
\hline $\mathbf{1}$ & Tanah Kering & $\mathbf{1 3 3 . 0 4}$ & $\mathbf{1 3 . 0 6 \%}$ \\
$\mathbf{2}$ & Permukiman & 95.39 & $9.37 \%$ \\
$\mathbf{3}$ & Tanah Kosong & 108.85 & $10.69 \%$ \\
$\mathbf{4}$ & Perairan & 61.77 & $6.06 \%$ \\
$\mathbf{5}$ & Perkebunan & $\mathbf{6 0 7 . 1 6}$ & $59.61 \%$ \\
$\mathbf{6}$ & Jalan & $\mathbf{1 2 . 3 2}$ & $\mathbf{1 . 2 1} \%$ \\
\hline
\end{tabular}

Sumber : Hasil Pengolahan Citra Google Earth

Berdasarkan tabel 2 terdapat 6 penggunaan tanah pada hamparan HGU yang dijadikan objek penelitian. Penggunaan tanah perkebunan memiliki prosentase terbesar dari keseluruhan luas objek penelitian yaitu sebesar 59.61\% atau 607.16 hektar. Penggunaan perkebunan berdasarkan interpretasi peta di atas hampir menyebar di seluruh lokasi HGU dan jika diamati dari citra google earth true colour, tanaman yang berada pada penggunaan ini adalah berupa tanaman keras. Kemudian penggunaan tanah kering dan tanah kosong berada pada posisi kedua dan ketiga dimana prosentasenya sebesar 13.06\% dan $10.69 \%$. Penggunaan tanah kering yang dimaksud adalah kenampakan pada citra yang menunjukkan bahwa di atas permukaan tanah tidak terdapat vegetasi, sedangkan tanah kosong adalah kondisi dimana di atas permukaan tanah tidak terdapat tanaman keras. Penggunaan permukiman menempati posisi ketiga dengan luas 95.39 hektar atau sekitar 9.37\% dari luas keseluruhan. Jika dilihat dari pola persebaran yang tampak pada citra, pola persebaran permukiman di kawasan HGU ini berada memanjang sejajar dengan pola penggunaan tanah berupa jalan. Penggunaan eksisting yang terakhir adalah perairan (6.06 $\%)$ dan jalan (1.21\%).

\section{Analisis Kesesuaian dan Ketidak- sesuaian Penggunaan Tanah}

Klasifikasi tutupan tanah/penggunaan tanah eksisting yang diperoleh dari citra google earth tahun 2017 ini berfungsi untuk menyajikan interpretasi penggunaan tanah pada lokasi HGU (atau dapat pula berupa hak lainnya). Analisis kesesuaian dan ketidaksesuaian penggunaan tanah didasarkan pada arahan hak yang ditetapkan dalam SK Hak yang diberikan kepada pemegang hak (perorangan/perusahaan). Hasil interpretasi yang menunjukkan adanya kesesuaian dan ketidaksesuaian antara penggunaan tanah eksisting dengan arahan hak penggunaan tanah (perkebunan karet) disajikan pada gambar 5 berikut.

Gambar 5. Hasil Interpretasi Kesesuaian dan Ketidaksesuaian Penggunaan Tanah di Lokasi Penelitian 5.a. Arahan Penggunaan tanah sesuai SK Hak/ penggunaan tanah perkebunan, 5b Penggunaan tanah tidak sesuai berupa pemukiman, 5.c Rona dan warna merah berupa tanah kering, 5.d. penggunaan tanah warna kuning berupa tanah kosong

\section{5.a. Perkebunan}

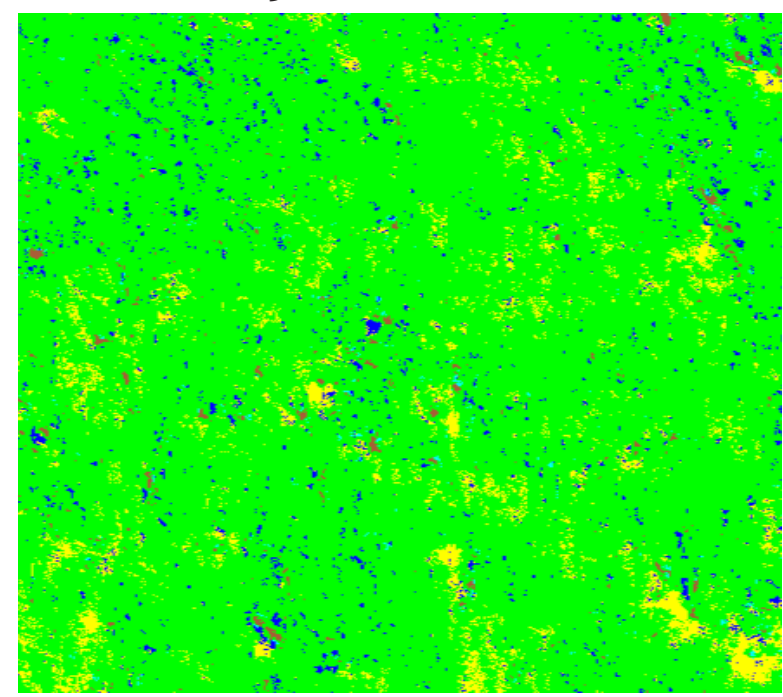


5.b. Permukiman



5.c. Tanah Kering

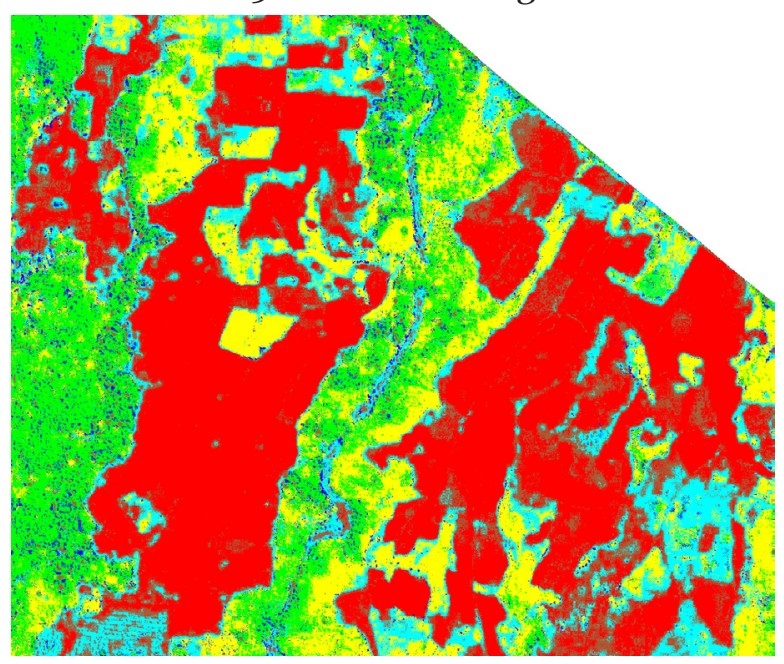

5.d. Tanah kosong

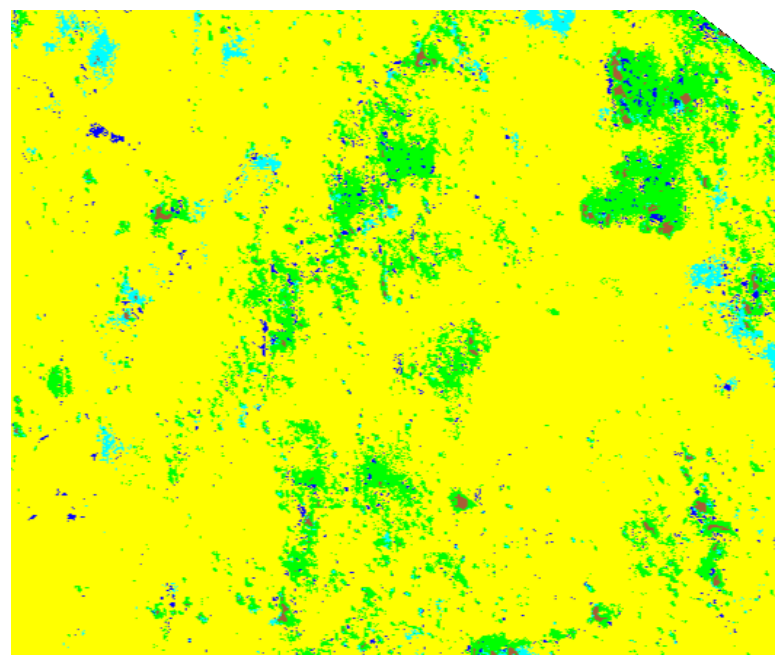

(Sumber: Hasil Analisis Data 2018)

Gambar 5 menunjukkan bahwa perusahaan yang diberikan izin HGU untuk arahan penggunaan perkebunan secara eksisting tidak semuanya diusahakan sebagai lahan perkebunan.
Hasil interpretasi dan klasifikasi tersebut menunjukkan lahan HGU yang seharusnya ditanami tanaman karet dimanfaatkan sebagai pemukiman dan beberapa lahan lainnya dibiarkan menjadi lahan kering. Selain itu hasil interpretasi juga menunjukkan bahwa penggunaan lahan yang seharusnya diusahakan untuk tanaman karet masih ada yang tidak diusahakan dalam artian dari hasil interpretasi masih berupa tanah kosong.

Berdasarkan hasil analisis pengolahan citra google earth terhadap keseluruhan kawasan Hak Guna Usaha pada lokasi penelitian maka beberapa jenis penggunaan tanah yang tidak sesuai dengan arahan hak serta luasan penggunaan tanah yang tidak sesuai dengan izin yang diberikan untuk pemegang hak disajikan pada tabel 3 .

\section{Tabel 3. Klasifikasi dan Luas Penggunaan}

Tanah Tidak Sesuai dengan Izin Hak

\begin{tabular}{lllll}
\hline No & $\begin{array}{l}\text { Penggunaan } \\
\text { Tanah }\end{array}$ & Kesesuaian & Luas (Ha) & Prosentase \\
\hline $\mathbf{1}$ & Tanah Kering & Tidak sesuai & 133.04 & $13.06 \%$ \\
$\mathbf{2}$ & Permukiman & Tidak sesuai & 95.39 & $9.37 \%$ \\
$\mathbf{3}$ & Tanah Kosong & Tidak sesuai & 108.85 & $10.69 \%$ \\
$\mathbf{4}$ & Perairan & sesuai & 61.77 & $6.06 \%$ \\
$\mathbf{5}$ & Perkebunan & sesuai & 607.16 & $59.61 \%$ \\
$\mathbf{6}$ & Jalan & sesuai & $\mathbf{1 2 . 3 2}$ & $\mathbf{1 . 2 1} \%$ \\
\hline
\end{tabular}

Sumber: Analisis Pengolahan Data Tahun 2018

Dari tabel 3 terlihat bahwa terdapat 3 penggunaan tanah pada wilayah penelitian yang tidak sesuai dengan arahan penggunaan ketika diterbitkannya izin HGU. Pertama, terdapat 133.04 hektar atau sebesar 13.06\% area pada lokasi penelitian penggunaanya berupa tanah kering. Kondisi ini mengindikasikan bahwa perusahaan ini kemungkinan memiliki faktor ketidaksengajaan ataupun sengaja menelantarkan tanahnya. Faktor ketidaksengajaan dapat dipengaruhi oleh faktor ketidakpahaman pemegang HGU terhadap mana saja lahan HGU yang harus diusahakan atau dapat pula dikarenakan pada lokasi tanah kering/terlantar tersebut secara geomorfologis 
tidak memungkinkan untuk digarap. Sementara itu, faktor kesengajaan dapat dipengaruhi karena ketidakmampuan perusahaan dalam mengusahakan tanah, hal ini berkaitan dengan keterbatasan modal yang dimiliki perusahaan atau dapat pula kesengajaan pemegang hak karena faktor spekulasi terhadap kenaikan harga tanah. Ketidaksesuaian kedua adalah permukiman yang mencapai 95.39 hektar atau sekitar 9.37\% dan ketiga adalah penggunaan tanah kosong seluas 108.85 hektar atau 10.69\%.

Pemanfaatan Sitem Informasi Geografispada penelitian ini di antaranya untuk menyajikan representasi sebaran spasial dan mengetahui luas setiap penggunaan tanah pada hasil klasifikasi citra. Pemanfaatan aplikasi SIG dalam penelitian ini hanya sebatas pada penyimpanan data, pengolahan data, dan penyajian data spasial untuk penggunaan tanah hasil interpretasi citra. Dikarenakan penelitian masih sebatas desk study (memanfaatakan data sekunder berupa citra dan peta HGU) dan belum melakukan kroscek/survei terhadap kondisi lapangan yang sebenarnya maka uji akurasi terhadap hasil interperetasi belum dilakukan dalam kajian ini, sehingga harapan ke depan adalah perlunya dilakukan penelitian lebih lanjut terkait bagaimana uji akurasi hasil interpretasi citra google earth serta mendalami lebih lanjut terkait mengapa tidak semua lokasi yang telah diberikan izin diusahakan oleh perusahaan. Kajian terhadap bagaimana dan siapa saja yang mengusahakan dan memanfaatkan tanah pada lokasi HGU dan kenapa ini dapat terjadi tentunya menjadi kajian menarik untuk dilakukan penelitian lanjut. Data serta informasi lanjutan tersebut akan mudah diinput dan diolah melalui SIG, sehingga pembaharuan serta pengolahan data lebih lanjut terkait tanah terlantar akan mudah dilakukan dengan memanfaatkan aplikasi ini.

Dari hasil pengolahan data diketahui luas total daerah penilitian ini adalah 1018.53 hektar, dimana jika dijumlah dari ketiga penggunaan tanah yang tidak sesuai terdapat 337.28 hektar atau sekitar 33.11\%. Berdasarkan pengolahan data ini maka dapat disimpulkan bahwa pemegang HGU tidak mengusahakan keseluruhan area yang telah diberikan hak untuk digarap sebagaimana izin yang ditetapkan untuk perkebunan dan hasil analisis ini menunjukkan bahwa terdapat 337.28 hektar dari wilayah HGU yang memiliki potensi terindikasi terlantar. Sebaran spasial terhadap tanah yang terindikasi terlantar pada kawasan HGU disajikan pada gambar 6.

\section{Gambar 6. Peta Terindikasi Terlantar Pada Kawasan HGU}

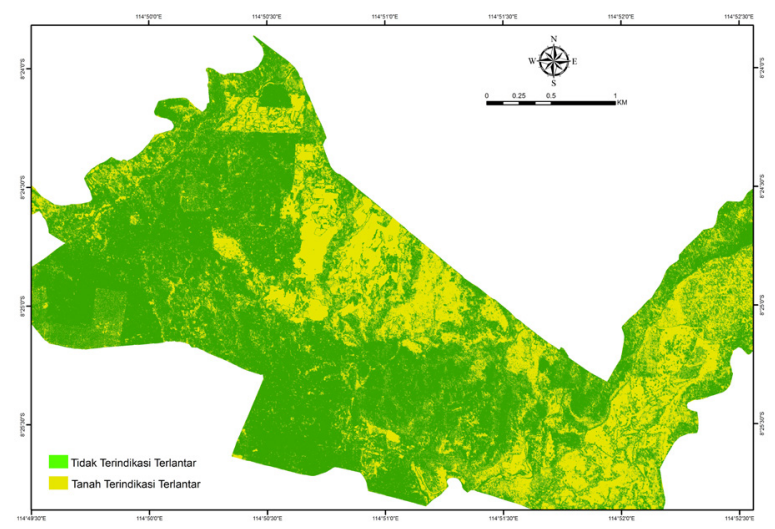

Sumber: Analisis Data Tahun 2018

\section{Percepatan Identifikasi Tanah Terindikasi Terlantar}

Hamparan tanah yang diterlantarkan/ terlantar di berbagai lokasi di Indonesia tentunya membutuhkan perhatian, penanganan, dan penyelesaian lebih serius lagi. Penertiban dan pendayagunaan tanah terlantar yang menjadi kewenangan Kementerian ATR/ BPN, dapat dimulai dengan tahapan awal yaitu identifikasi terhadap tanah-tanah yang telah diberikan izin HGU ataupun hak lainnya.

Citra penginderaan jauh yang tersaji secara gratis dan disajikan oleh berbagai provider tentunya dapat membantu mempermudah dan mempercepat pekerjaan identifikasi tanah 
terindikasi terlantar. Beberapa citra yang dapat diunduh secara gratis dan dapat dimanfaatkan untuk pengolahan citra secara digital selain google earth adalah Landsat 8 yang tersaji dengan berbagai pilihan yaitu gelombang visible (Red, Green, Blue), gelombang inframerah dekat dan gelombang thermal, Landsat 7 (Johnson 2015, 13436-13439).

Pemanfaatan citra secara digital ini dapat dilakukan secara efektif dan efisien untuk mengetahui eksisting penggunaan tanah terbaru pada lokasi tanah yang telah diberikan izin hak. Kelebihan citra penginderaan jauh yang mampu menyajikan data secara temporal juga dapat dimanfaatkan untuk memantau perubahan penggunaan lahan secara cepat, efektif dan efisien (Pattanayak 2016, 201213 ). Tingkat akurasi yang tinggi dari hasil interpretasi dan klasifikasi penggunaan tanah melalui analisis citra digital serta kemampuan menyajikan data terbaru dapat dimanfaatkan untuk perencanaan dan pengelolaan sumber daya alam berkelanjutan (Mishra 2016, 4553). Kegiatan percepatan identifikasi tanah terlantar dengan pemanfaatan citra dan SIG ini diharapkan menjadi langkah awal untuk menertibkan tanah terlantar dan mendorong pendayagunaan tanah untuk masyarakat melalui reforma agraria.

\section{E. Kesimpulan}

1. Citra google earth merupakan salah satu citra yang disajikan oleh digital globe dengan resolusi spasial cukup tinggi, tersaji secara bebas/tidak berbayar dan dapat diakses dengan mudah. Citra ini memberikan keunggulan untuk monitoring dan analisis penggunaan tanah.

2. Pemanfaatan citra google earth dan SIG dapat digunakan untuk mempercepat identifikasi tanah terlantar. Metode yang digunakan melalui analisis ketidaksesuaian antara penggunaan tanah eksisting terhadap arahan izin penggunaan tanah pada hak (Hak Guna Usaha, Hak Guna Bangunan, Hak Pakai, Hak Pengelolaan) yang telah ditetapkan dalam SK pemberian hak.

3. Klasifikasi supervised dengan menggunakan algoritma maxsimum likelihood memudahkan user dalam melakukan analisis klasifikasi penggunaan tanah.

4. Hasil penelitian menunjukkan bahwa pada area HGU yang diberikan kepada pemegang hak terdapat 337.28 hektar atau sekitar $33.11 \%$ penggunaan tanah yang tidak sesuai dengan arahan izin yang diberikan. Terhadap tanah seluas $33.11 \%$ atau 337.28 hektar tersebut dapat dikategorikan menjadi tanah yang teridentifikasi terlantar.

5. Kemajuan teknologi penginderaan jauh dan SIG ini hendaknya menjadi peluang dan dapat dimanfaatkan seoptimal mungkin bagi Kementerian ATR/BPN untuk meningkatkan kinerja guna mencapai target yang telah ditetapkan.

\section{Daftar Pustaka}

A.Collin, K. Nadaoka, and T Nakamura 2014, ISPRS International Journal of Geoinformation, 3, 1157.

A. Farah, and D. Algarni 2014, Artificial Satellites. 49-2, 101.

Ahmad, A. \& Quegan, S 2012, Analysis of maximum likelihood classification on multispectral data. Applied Mathematical Sciences 6 (129), 6425 6436.

Amran, A. Muhammad 2017, 'Mapping seagrass condition using google earth imagery', Journal of Engineering Science and Technology. 
Bey Adia, et all 2016, Collect Earth: 'Land use and land cover assessment through augmented visual interpretation', Remote Sensing Journal, www. mdpi.com/journal/remotesensing. doi:10.339o/rs8100807

Bronsveld, M.C. Kostwinder, H.R., \& Chutirrattanapan, S 1992, Improving a land use map using geo-information systems and remote sensing. Paper Presented at The Second Symposium on Remote Sensing and Space, Hat Yai.

Danoedoro, Projo 2012, Pengantar Penginderaan Jauh Digital, Andi Offset, Yogyakarta.

Goldblatt Ran, Wei You, Gordon Hanson, Amit K. Khandelwal 2016, 'Detecting the boundaries of urban areas in India a dataset for pixel-based image classification in google earth engine', Remote Sensing Journal, www.mdpi. com/journal/remotesensing, 634, doi:10.339o/rs8o8o634

Hird N Jennifer, Evan R. DeLancey, Gregory J. Mc Dermid Jahan Kariyeva, 2017, 'Google earth engine, open-access satellite data, and machine learning in support of large-area probabilistic wetland mapping', Remote Sensing Journal, ， www.mdpi.com/journal/ remotesensing. 1315, doi: 10.3390/ rs9121315

Johnson A. Brian 2015, Scale issues related to the accuracy assessment of land use/ land cover maps produced using multiresolution data: comments on "The improvement of land cover classification by thermal remote sensing". Institute for Global Environmental Strategies, 210811 Kamiyamaguchi, Hayama, Kanagawa 240-0115, Japan, www.mdpi.com/ journal/remotesensing, 13436-13439, doi:10.339o/rs71013436
Lillesand, T.M., Kiefer, R.W 2008, Remote sensing and image interpretation. New York: Wiley.

Lu, D., Batistella, M., Moran, E., Hetrick, S., Alves, D., Brondizio, E 2011, 'Fractional forest cover mapping in the Brazilian Amazon with a combination of MODIS and TM images'. Int. J. Remote Sens. 32, 7131-7149. Doi: 10.1080/01431161.2010.519004

Mishra Varun Narayan, Praveen Kumar RAI, Pradeep KUMAR, Rajendra Prasad 2016, Evaluation of land use/land cover classification accuracy using multiresolution remote sensing images, Forum geografic. Studii și cercetări de geografie și protecția mediului, Volume $\mathrm{XV}$, Issue 1, pp. 45-53 http://dx.doi. org/10.5775/fg.2016.137.i.

Pattanayak Surya Prakash, Diwakar Kumar Sumant 2016, 'District-wise change analysis of land use-land cover in Delhi territory using remote sensing \& GIS', Journal of Urban and Environmental Engineering, Vol. 10, No. 2. p.201-213, doi: 10.409o/juee2016.v10n2.201213.

Pulighe Giuseppe, Baiocchib Valerio, Lupiaa Flavio 2015, 'Horizontal accuracy assessment of very high resolution Google Earth images in the city of Rome Italy', International Journal of Digital Earth, $\mathrm{P}_{342-362}$

Schmidt M.A Reolon, Jaciane Xavier Bressiani, Patrícia Antunes DosReis and Marcio Ricardo Salla 2016, 'Evaluation of the performance of image classification methods in the identification of vegetation', Journal of Urban and Environmental Engineering, v.10, n.1, p.o62-071, Celso Augusto Guimarães Santos, http://www.jstor.org/ stable/26240813. doi: 10.409o/juee.2016. vion1.062071. 
Laporan Kinerja Kementerian Agraria dan Tata Ruang/Badan Pertanahan Nasional Tahun 2015, 2016 dan 2017, diakses melalui http://www.bpn.go.id.

\section{Peraturan Perundangan}

Peraturan Presiden Nomor 11 Tahun 2010 tentang Penertiban dan Pendayagunaan Tanah Terlantar

Peraturan Presiden Republik Indonesia Nomor 26 Tahun 2015 tentang Kantor Staf Presiden.

Peraturan Kepala Badan Pertanahan Nasional Nomor 4 Tahun 2010 tentang Tata Cara Penertiban Tanah Terlantar.

Peraturan Presiden Republik Indonesia Nomor 2 Tahun 2015 Tentang Rencana Pembangunan Jangka Menengah Nasional Tahun 2015-2019. 